\title{
PENDEKATAN NEGARA HUKUM KRISIS EKONOMI: SEBUAH JALAN TENGAH
}

\author{
Yafet Yosafet Wilben Rissy \\ Fakultas Hukum Universitas Kristen Satya Wacana \\ J1. Diponegoro 52-60 Salatiga \\ yafet.rissy@uksw.edu
}

\begin{abstract}
This article discusses a proper new approach to the rule of law to be applied in an economic emergency (the economic crisis rule of law). This new approach is a breakthrough (middle way) to avoid the conflict between the notion that prioritizing legal and constitutional constraints to the president (executive) and those whom reject this notion in an emergency situation. In an economic crisis, an emergency law should not rigidly restrict the power and discretionary actions of the president, but it should also not to grant unlimited power and discretionary actions to the president. Under the perspective of the economic crisis rule of law, the emergency law should be efficient, rational, certain and predictable so it could stabilize the economic crisis and achieve economic prosperity.
\end{abstract}

Keywords: Approach; Economic Crisis; Emergency Law; Legal and Constitutional Constraints, Power.

\begin{abstract}
Abstrak
Artikel ini membahas pendekatan baru atas model negara hukum yang tepat untuk diterapkan dalam keadaan darurat ekonomi (the economic crisis rule of law). Pendekatan baru ini merupakan terobosan (jalan tengah) untuk menghindari konflik antara paham yang mengutamakan pembatasan hukum dan konstitusional kepada presiden (eksekutif) dan mereka yang menolak paham ini dalam situasi darurat. Dalam krisis ekonomi, hukum darurat tidak boleh secara kaku membatasi kekuasaan dan tindakan diskresi presiden, tetapi juga tidak boleh memberikan kekuasaan dan tindakan diskresi yang tidak terbatas kepada presiden (eksekutif). Dalam perspektif negara hukum krisis ekonomi, hukum darurat harus efisien, rasional, pasti dan dapat diprediksi sehingga dapat menstabilkan krisis ekonomi dan mencapai kemakmuran ekonomi.
\end{abstract}

Kata Kunci: Pendekatan; Krisis Ekonomi; Hukum Darurat; Pembatasan Hukum dan Konstitusi; Kekuasaan.

\section{A. Pendahuluan}

Pendekatan negara hukum (rule of law approach) dalam keadaan normal perlu dibedakan dari pendekatan negara hukum (rule of law approach) dalam keadaan krisis. Tetapi mengingat substansi dan hakikatnya yang berbeda, perlu dibedakan lagi hukum darurat dalam krisis politik dari hukum darurat dalam krisis ekonomi, baik yang diakibatkan oleh fundamental ekonomi 
yang miskin maupun karena bencana alam atau pandemik penyakit tertentu, misalnya pandemi Covid-19, serta krisis bencana alam lainnya (Rissy, 2020).

Di Indonesia maupun di berbagai negara lainya paham konstitusionalisme yang menganggungkan prosedur dan tata cara pembuatan undang-undang baik atas dasar inisiatif Dewan Perwakilan Rakyat (DPR) maupun sebaliknya Presiden valid ketika kondisi negara dalam keadaan normal. Proses pembuatan undang-undang dalam keadaan normal memakan waktu dan biaya serta tekanan politik yang tinggi. Dalam konteks normal, syarat dan tata cara pembuatan undang-undang tentu harus dipatuhi, termasuk pembatasan hukum dan konstitusi (legal and constitutional constraints ataupun liberal legalism) (Zywicki, 2015) atas kewenangan dan diskresi pemerintah (baca Presiden atau eksekutif). Tentu, dalam keadaan normal, karena tingkat kebutuhan atas undang-undang tersebut tidak urgen, persoalan pembatasan di atas termasuk kepatuhan atas prinsip negara hukum bisa dipahami.

Persoalannya berbeda ketika negara dalam keadaan darurat, baik politik atau ekonomi, proses normal pembentukan undang-undang tidak bisa diterapkan. Oleh karenanya, diperlukan pendekatan negara hukum yang tepat untuk memoderasi situasi krisis ekonommi dan politik tersebut sehingga hukum dapat memitigasi berbagai krisis tersebut dengan baik. Di banyak negara, termasuk Indonesia sesuai ketentuan Pasal 22 UUD 1945, konsitusi mengatribusi Presiden kewenangan untuk membentuk undang-undang jika negara dalam keadaan darurat, baik politik, keamanan maupun ekonomi. Dalam darurat ekonomi, umumnya, Presiden mengambil segala langka yang dianggap perlu untuk menstabilkan krisis politik. Dalam situasi darurat politik seringkali Presiden bertindak tanpa batas dan melanggar hukum itu sendiri. Isu yang menantang ialah apakah dalam darurat ekonomi, presiden juga dapat bertindak tanpa batas dan dapat melanggar hukum dan konstitusi? Ataukah kewenangan dan tindakan diskresi Presiden (eksekutif) dibatasi oleh hukum dan konstitusi itu sendiri? Apakah kedua titik ekstrim ini bisa dipertemukan dalam krisis ekonomi? Jika ya, bagaimana caranya? Atau model pendekatan negara hukum apakah yang tepat diterapkan dalam darurat ekonomi?

Tulisan ini dimaksudkan untuk menjawab pertanyaan-pertanyaan di atas dimana Penulis mengusulkan dan menjelaskan suatu pendekatan negara hukum (rule of law) yang dapat dipakai untuk memitigasi krisis ekonomi yang dihadapi negara manapun, termasuk Indonesia, yang Penulis sebut sebagai the Economic Crisis Rule of Law Approach (Pendekatan Negara Hukum Krisis Ekonomi). Sebenarnya ide untuk menerapkan model negara hukum yang tepat dalam krisis ekonomi dan keuangan telah ditulis oleh sejumlah ahli hukum ternama di antaranya Prof. Bernadette Meyler (Meyler, 2007), Alain Supiot (Supiot, 2010), Alun Gibss (Gibbs, 2016), Prof. Claire Kilparict (Kilpatrick, 2015), Namun, pembahasannya lebih mempersoalkan konsep negara hukum klasik yang menekankan pencapain tujuan negara hukum hukum formil dan substantif tanpa secara spesifik melekatkan ciri fundamental yang seharusnya diperhatikan dalam bernegara hukum dalam krisis ekonomi. Penulis kemudian datang dengan ide yang mencoba menkonstruksi model negara hukum krisis ekonomi dimana Penulis mencoba membangun sebuah model negara hukum krisis ekonomi yang memiliki sejumlah ciri fundamental yang secara inheren melekat di dalamnya. Inilah yang membedakanya pandangan Penulis dengan para ahli hukum yang telah disebutkan di atas.

Oleh karenanya, untuk mencapai maksud di atas, pertama, tulisan ini akan menjelaskan terlebih dahulu konsep negara hukum dan tujuannya. Di bagian ini akan diuraikan bagaimana konsepsi negara hukum meletakan fondasi bagi pembentukan hukum (undang-undang) dan tujuan negara hukum. Kedua, pembahasan dilanjutkan dengan menjelaskan konstitutionalisme kedaruratan yang memberi perhatian khusus pada legal and constitutional constraints vs unlimited power discretionary actions. Di bagian ini, akan dielaborasi syarat kedaruratan yang digariskan konstiusi yang menjadi dasar bagi negara (baca: pemerintah cq. Presiden) untuk menggunakan hak prerogatif konstitusional dalam membuat undang-undang. Juga diuraikan pokok sengketa atau ketegangan teoritis antara ide ketaatan pada konsep negara hukum termasuk 
liberal legalism (legal and constitutional constraints) di satu pihak yang berhadap-hadapan unlimited power and discretionary actions di pihak lainnya.

Ketiga, Penulis memberi perhatian kepada pendekatan yang idealnya dipakai ketika negara dalam keadaan darurat ekonomi. Di bagian ini, Penulis berusaha mendamaikan ketegangan antara paham negara hukum termasuk liberal legalism (legal and constitutional constraints) dan unlimited power and discretionary actions oleh Presiden (eksekutif) dengan mengusulkan sebuah pendekatan yang coexist (berdampingan) antara negara hukum dan darurat ekonomi. Dalam konteks ini, Penulis mengusulkan model jalan tengah (the middle way) yakni the economic crisis of rule of law approach (pendekatan negara hukum krisis ekonomi).

\section{B. Pembahasan}

\section{Negara Hukum (Rule of Law)}

Negara hukum (rule of law) merupakan konsep ideal dalam sebuah negara modern. Hampir semua negara di dunia, mendeklarasikan dirinya sebagai negara yang berdasarkan atas hukum atau negara hukum (rule of law). Konsepsi negara hukum, telah dibahas secara meluas oleh banyak ahli hukum di antaranya Sellers and Thomaszewski (Sellers, 2010), Brudner (Brudner, 1995), Forst (Forst, 1994), Licht, Glodsmith and Schwartz (Licht, 2007), O’Donnell (O’Donnell, 2004) dan Scaliat (Scaliat, 1989). Dari semua ulasan di atas, setidaknya terdapat dua prinsip yang perlu digarisbawahi ketika berbicara mengenai negara hukum. Pertama, negara hukum sebenarnya tidake lebih dan tidak kurang dari sebuah fenomena umum yuridis yang harus dipenuhi dalam sebuah sistem hukum. Kedua, konsep negara hukum juga merujuk pada sebuah ekspresi komitmen moral terhadap penegakan martabat dan persamaan individu atau manusia (Kramer, 2007).

Terdapat banyak teori yang dapat menjelaskan bagaimana mewujudkan konsep negara hukum di atas, namun di kesempatan ini, Penulis ingin merujuk kepada konsep negara hukum dalam perspektif teori formal (Formal Theories of Rule of Law). Teori formal rule of law (Tamanaha, 1994), dari sisi tujuannya dan pembentukannya membagi negara hukum atas dua: negara hukum formil (formal rule of law) dan negara hukum subtantif (substantive rule of law).

Dalam negara hukum subtantif (substantive rule of law), hukum bertujuan untuk mencapai perlindungan atas hak-hak individu baik kekayaan, kontrak, privasi maupun otonominya, lalu meningkat ke perlindungan atas hak atas martabat dan/keadilan, dan puncaknya adalah untuk mencapai kesejahteraan sosial (social welfare) dimana hukum ingin mencapai persamaan substantif, kesejahteraan, dan perlindungan kepada masyarakat (Tamanaha, 1994).

Kebalikan dari konsep negara hukum substantif adalah konsep negara hukum formil (formal rule of law). Di dalamnya, yang dikejar bergerak dari tingkatannya yang paling rendah rule-bylaw dimana hukum diposisikan sebagai instrumen yang spesifik (khusus) yang mendasari tindakan pemerintah, lalu meningkat menjadi legalitas formal (formal legality) dimana hukum bersifat umum, fokus ke masa depan, pasti dan jelas, dan meningkat lagi menjadi demokrasi plus legalitas (democracy + legality) dimana persetujuan menentukan konten hukum melalui proses politik. Dalam pandangan Tamanaha (1994) negara hukum formal terdiri atas semata prinsip hukum yang mengarahkan dan membatasi pembuatan dan penerapan hukum subtantif (materil) umumnya dan merupakan subyek terhadap konsensus yang lebih besar atas makna hukum.(Tamanaha, 1994)

Lebih lanjut MacCormick, Peerenboom, Fuller, dan Killer sebagaimana dirangkum Maxeiner (Maxeiner, 2007), menjelaskan bahwa elemen utama dari negara hukum formal adalah bahwa hukum harus dibuat secara absah dan diumumkan (diundangkan) ke publik mengenai penerapan, hukum harus stabil, memiliki arti yang jelas, konsisten dan bersifat masa depan. Dalam perspektif ini, hukum mengatur persyaratan penerapan hukum, dimana prinsipnya adalah hukum tidak boleh memihak (impartial), memberikan kepada pihak yang dihukum 
kesempatan untuk didengarkan dan hukum harus dapat diprediksi (predictable), dan hukum harus memberikan keputusan yang konsisten ketika terdapat kasus-kasus yang bersifat individual.

Dari penjelasan di atas, dalam bahasa yang ringkas dapat disimpulkan bahwa rule of law bertujuan untuk menciptakan kepastian dan keadilan hukum (legal certainty and justice) baik keadilan hukum formil (legal and formal justice) maupun keadilan substantif (legal and substantive justice) (Altman, 2001) dan untuk mencapai perlindungan martabat manusia dan kemakmuran sosial.

\section{Konstitutionalisme Kedaruratan: dari Minimum Standar hingga Liberal Legalism}

Konstitusi dan yang kemudian diterjemahkan lebih lanjut dalam undang-undang di berbagai negara memberikan klausula bagi Eksektufif (Presiden, Perdana Menteri, Kanselor, atau kepala pemerintahan lainnya) untuk membentuk undang-undang dalam keadaan darurat, termasuk kewenangan bertindak untuk mengatasi keadaan darurat. Dalam hal keadaan darurat misalnya, di Jerman, Pasal 48 Konstitusi Weimar (1919-1933) menyatakan "If public security and order are seriously disturbed or endangered within the German Reich, the President of the Reich may take measures necessary for their restoration, intervening if need be with the assistance of the armed forces." Kanselor Jerman memiliki hak konstitisional untuk bertindak, termasuk membuat undang-undang, jika negara dalam keadaan darurat. Tentu ini rumusan Pasal 48 di atas merujuk pada darurat politik/perang/pertahanan.

Di Amerika, jika terjadi major disasters and national emergencies, Presiden, sesuai Stafford Act 2008 concerning Disaster Relief and Emergency Assistance, memiliki kewenangan eksekutif tanpa persetujuan kongres untuk bertindak mengatasi bencana dan dampaknya. Sesuai namanya, UU Stafford merujuk pada darurat bencana alam. Masih di Amerika, ketika terjadi darurat kemanan dan pertahanan nasional, yang disebabkan oleh serangan teroris dalam peristiwa 9/11 2001, Presiden George Bush, Jr. mendeklarakasi darurat nasional dan mengeluarkan undang-undang yang dikenal sebagai Patriot Act 2001. Bahkan di Amerika, sesuai investigasi the Brennan Centre terdapat 136 undang-undang yang memberi kewenangan Presiden untuk bertindak ketika negara dinyatakan dalam keadaan darurat (Farber, 2020).

Sementara itu, di Indonesia, Pasal 22 ayat (1)(2)(3) UUD 1945 memberikan landasan konstitusi bagi Presiden untuk mengeluarkan PERPU dalam hal ihwal kegentinghan yang memaksa. Pasal 22 UUD 1945 menyatakan:

(1) Dalam hal ihwal kegentingan yang memaksa, Presiden berhak menetapkan peraturan pemerintah sebagai pengganti undang-undang.

(2) Peraturan pemerintah itu harus mendapat persetujuan Dewan Perwakilan Rakyat dalam persidangan yang berikut.

(3) Jika tidak mendapat persetujuan, maka peraturan pemerintah itu harus dicabut.

Ketentuan Pasal 22 UUD 1945 di atas ditegaskan lagi dalam Pasal 1 angka 4 UU No 12 Tahun 2011 tentang Pembentukan Peraturan Perundang-Undangan menyatakan: 'Peraturan Pemerintah Pengganti Undang-Undang adalah Peraturan Perundang-undangan yang ditetapkan oleh Presiden dalam hal ihwal kegentingan yang memaksa'. Terhadap makna 'hal ihwal kegentingan yang memaksa', Asshiddiqie (2010) berpendapat bahwa frasa tersebut bermakna suyektif sehingga hanya Presiden yang bisa menilainya. Selengkapnya Asshiddiqie (2010) berpendapat sebagai berikut:

"Pasal 22 memberikan kewenangan kepada Presiden untuk secara subjektif menilai keadaan negara atau hal ihwal yang terkait dengan negara yang menyebabkan suatu undang-undang tidak dapat dibentuk segera, sedangkan kebutuhan akan pengaturan materiil mengenai hal yang perlu diatur sudah sangat mendesak sehingga Pasal 22 UUD 1945 memberikan 
kewenangan kepada Presiden untuk menetapkan peraturan pemerintah pengganti undangundang (Perpu)". (Asshiddiqie, 2010)

Namun demikian, atas untuk menghindari interpretasi yang subyektif di atas, Mahkamah Konstitusi dalam Putusan MK Nomor 138/PUU-VII/2009 memberikan tiga ukuran obyektif untuk menilai keadaan darurat atau hal ikwal kegentingan memaksa oleh Presiden dalam mengelurkan PERPU tersebut yakni: a) Adanya keadaan yaitu kebutuhan mendesak untuk menyelesaikan masalah hukum secara cepat berdasarkan Undang-Undang; b) Undang-Undang yang dibutuhkan tersebut belum ada sehingga terjadi kekosongan hukum, atau ada UndangUndang tetapi tidak memadai; dan, c) Kekosongan hukum tersebut tidak dapat diatasi dengan cara membuat Undang-Undang secara prosedur biasa karena akan memerlukan waktu yang cukup lama sedangkan keadaan yang mendesak tersebut perlu kepastian untuk diselesaikan. (Putusan MK Nomor 138/PUU-VII/2009, 2009)

Jika dicermati tiga ukuran obyektif di atas, terlihat bahwa ukuran tersebut sangat umum sekaligus minimum karena hanya mendefinisikan adanya keadaan berupa kebutuhan mendesak, adanya kekosongan hukum atau adanya undang-undang tetapi tidak memadai dan menghindari pembuatan undng-undang normal yang memerlukan waktu yang panjang. Jadi ini terkait cara pembuatan hukum yang dianggap lebih cepat untuk mengatasi krisis.

Namun demikian ukuran obyektif di atas sama sekali tidak menyentuh aspek substansi Undang-Undang darurat dan kekuasaan dan tindakan diskresi yang dimiliki Presiden dalam membuat hukum (Undang-Undang dan bagaimana batasan-batasan yang harus diperhatikan Presiden (eksekutif) dan dalam mengambil diskresi. Oleh karenaya, aspek substansi Perppu dan diskresi Presiden sepenuhnya menjadi tanggungjawab dan suyektifitas Presiden. Sekali lagi, sampai pada titik ini, jelas bahwa baik Pasal 22 UUD 1945, Pasal 1 angka 4 UU No 12 Tahun 2011 dan Putusan Mahkamah Konstitusi No. 138/PUU-VII/2009, sama sekali tidak menyentuh aspek substansi Perppu/UU tersebut dan batasan-batasan diskresinya.

Persoalan yang kemudian muncul ialah apakah Presiden bebas dan terlepas dari batasanbatasan dalam konstitusi (jika ada) dalam menentukan substansi Perpu/UU? Apakah Presiden bebas juga mengambil tindakan diskresi? Atau jika tidak ada pembatasan tersebut lalu bagaiamana seharusnya batasan tersebut dibuat? Dengan kata lain apakah Presiden (eksekutif) perlu mentaati hukum (rule of law) dalam membentuk Perppu/UU atau dalam mengambil tindakan diskresioner tanpa batas dalam keadaan darurat ekonomi?

Terdapat dua jawaban yang saling menentang atas pertanyaan di atas. Pertama, ada ahli hukum yang berpendapat bahwa dalam keadaan darurat Presiden (eksekutif) boleh melanggar hukum baik dalam pembentukan substansi hukum itu sendiri maupun tindakannya yang menyimpang dari hukum dalam bentuk diskresi. Kelompok ini diwakili oleh Profesor Erich Posner dan Profesor Adrian Vermeule. Keduanya berpendapat pembatasan hukum (legal and constitutional constrains atau liberal legalism) bagi Presiden (eksekutif) merupakan hal atau tindakan yang tidak bijaksana (unwise), tidak realistik (unrealistic) dan tidak perlu (unnecessary) (Posner, 2010).

Pembatasan hukum (legal constraints) bagi Presiden (eksekutif) tidak bijaksana (unwise) karena dalam keadaan krisis, baik keamanan nasional dan krisis ekonomi, pemerintah memerlukan tindakan cepat untuk mengatasi krisis dan hanya eksekutif yang memiliki kemauan dan fokus yang memadai untuk menstabilkan krisis tersebut. Hakikat krisis itu adalah ketidakpastian sehingga keterlambatan dalam memberi respons yang cepat hanya akan memperburuk situasi. Bagi Posner dan Vermeule (2010) proses peninjauan kembali atau tindakan pengawasan lainnya tidak relevan karena hanya akan memperlambat penanganan krisis (Posner, 2010).

Pembatasan hukum dan konstitusi (legal and constitutional constraints) bagi Presiden (eksekutif) juga tidak realistik (unrealistic) karena sekalipun dikenal pemisahan kekuasaan (legislatif, yudikatif dan eksekutif) sistem pemerintahan saat ini merupakan pemerintahan yang 
berpusat pada eksekutif. Pembatasan hukum hanya akan menghambat pemerintah untuk bertindak dengan kecepatan dan kekuatan yang diperlukan untuk memenuhi tuntutan publik. Akibatnya, liberal legalism, misalnya pembatasan hukum bagi diskresi eksekutif tidak dapat berfungsi di negara modern dan tidak dapat membatasi pemerintah dalam keadaan krisis (Posner, 2010).

Pembatasan hukum (legal constraints) bagi Presiden (eksekutif) juga tidak diperlukan (unnecessary) karena bagi keduanya, pembatasan informal (informal restrain) berupa opini politik dan opini publik, lebih efektif dan lebih berguna dibandingkan dengan pembatasan oleh aturan hukum (legal rules) atau hukum (laws). Oleh karenanya kekuatiran pihak yang mendukung legal liberalism bahwa batasan informal saja dapat memicu tirani atau kediktatoran tidak beralasan. Mengapa? Karena bagi Posner dan Vermeule, kekuatiran tersebut tidak akan terjadi karena secara de-facto pembatasan melalui opini publik dan opini politik telah ada dan berkembang, dan pada tingkat tertentu telah mengantikan pembatasan hukum bagi eksektutif (Posner, 2010).

Pendapat Posner dan Vermeule di atas ditentang keras oleh Profesor Sywicki yang menyatakan bahwa pendapat Posner dan Vermeule secara normatif mengandung cacat (Zywicki, 2015). Sywicki menyatakan dengan tegas bahwa sekalipun dalam keadaan krisis, kekuasaan presiden (eksekutif) tetap harus dibatasi oleh hukum (konstitusi) dan tindakan diskresi eksekutif juga harus dibatasi atau tidak sepenuhnya bebas. Profesor Sywicki memberikan empat alasan. Pertama, kepatuhan pada aturan hukum diperlukan untuk menopang pencapaian kemakmuran ekonomi secara umum, terlebih lagi selama krisis ekonomi. Kedua, kepatuhan terhadap supremasi hukum diperlukan untuk membendung oportunisme para politisi dan kepentingan khusus yang menggunakan kesempatan yang tercipta karena krisis untuk mendukung kepentingan sempit mereka sendiri, dan seringkali tanpa memiliki hubungan dengan masalah yang sebenarnya. Ketiga, begitu diskresi dilepaskan selama krisis, berakhirnya krisis tidak mendorong kembalinya supremasi hukum. Dan keempat, potensi tindakan diskresioner saja dapat meningkatkan moral hazard, sehingga menciptakan kondisi untuk intervensi lebih lanjut (Zywicki, 2015).

Bagi Penulis, dalam kerangka pikir Profesor Sywicki di atas, sesungguhnya negara hukum bertujuan untuk memastikan bahwa tindakan diskresi eksekutif dibatasi tidak hanya secara prosedural (formal) tetapi juga materil (substansi). Oleh karenanya, sebagaimana disentil Barnett Randy, sekalipun dalam krisis, kepatuhan atas prinsip negara hukum penting karena justure dalam kepatuhan itulah masyarakat (tentu termasuk negara, ditambahkan Penulis) diperbolehkan mengkombinasikan kebebasan, keadilan dan mengupayakan tatanan ekonomi yang lebih baik (Barnett, 1998).

\section{Pendekatan Negara Hukum Krisis Ekonomi: Sebuah Jalan Tengah}

Sebagaimana dijelaskan di atas terdapat pertentangan antara Profesor Posner dan Profesor Vermeule di satu sisi yang menolak pembatasan hukum atas Presiden (eksekutif) dalam keadaan krisis, sementara di pihak lainnya terdapat Profesor Sywicky yang menyatakan sebaliknya, pembatasan hukum atas kekuasaan presiden (eksekutif) dan pembatasan diskresi tetap diperlukan.

Bagi Penulis, ketegangan di atas perlu dicarikan jalan keluarnya. Thesis utama Penulis adalah di saat krisis ekonomi legal and constitutional constrains atas Presiden (eksekutif) dan diskresi dari Presiden (eksekutif) perlu dilonggarkan sehingga presiden (eksekutif) memiliki ruang cukup (flexible) untuk menentukan substansi hukum maupun untuk mengambil tindakan konkrit dalam mengatasi krisis. Tetapi di saat bersamaan pembatasan hukum dan tindakan konkrit diskresioner yang dilonggarkan oleh hukum tersebut haruslah pula dipertanggungjawabkan secara hukum. Inilah yang Penulis sebuat sebagai the economic crisis rule of law approach. 
Persoalannya ialah bagaimana mengkonstruksi the economic crisis rule of law approach ini? Sebelum menjawab isu ini, perlu kiranya dijelaskan bahwa sejauh ini, dalam kajian Profesor Bernadette Meyler, pendekatan negara hukum dalam keadaan darurat politik atau yang oleh Penulis disebut sebagai the political emergency rule of law approach (Rissy, 2020) jauh lebih familiar dan lebih menunjukan adanya keberhasilan dan dukungan global (Meyler, 2007).

Thesis utama dalam the political emergency rule of law approach ialah raison d'état yakni sebuah doktrin yang menyatakan bahwa 'apapun yang dipersyaratkan untuk memastikan keselamatan sebuah negara harus dilakukan oleh individu yang bertanggungjawab untuk itu, sekalipun tindakan tersebut bahkan dalam kapasitas individu tersebut sendiri merupakan sesuatu yang tidak layak dan ditolak secara moral'(Joachim, 1957). Sudah barang tentu, dalam perspektif doktrin raison d'état, pendekatan-pendekatan konstitutionalisme, legal liberalism ataupun legal constraints lainnya, termasuk diskresi tidak bisa dibatasi (unrestricted). Segala cara dapat ditempuh untuk menstabilkan krisis politik. Tentu, stabilitas politik dan kepentingan politik menjadi lebih utama dibandingkan hak-hak sipil, politik dan ekonomi. Ini dua kutup yang sulit berdamai.

Persoalannya ialah bahwa pendekatan the political emergency rule of law approach tidak dapat diterapkan dalam kondisi darurat ekonomi. Oleh karenannya, dibutuhkan pendekatan lainnya yang disebut Penulis sebagai the economic crisis rule of law approach. Dalam pendekatan ini, kepatuhan terhadap negara hukum tidak boleh meniadakan upaya untuk memulihkan darurat ekonomi karena rakyat juga memiliki hak konstitusional atas kehidupan yang nyaman, keadilan ekonomi dan hukum, serta kemakmuran. Sebaliknya pendekatan yang memberi kelonggaran dan kebebasan dalam bertindak melalui diskresi tidak boleh juga meniadakan kepatuhan atas prinsip negara hukum atau tidak boleh tanpa batas. Dalam konteks ini, diperlukan pendekatan yang coexist yang memungkinkan keduanya berjalan bersamaan untuk mencari keseimbangan negara hukum dan ekonomi.

Dalam pendekatan negara hukum krisis ekonomi (the economic crisis rule of law approach) ini sesunguhnya pertentangan antara Profesor Posner dan Profesor Vermeule sebagaimana dijelaskan di atas tidak seharusnya terjadi. Bagi Penulis, adalah benar di saat krisis (baik krisis politik maupun krisis ekonomi) legal constrains atas presiden (eksekutif) perlu dilonggarkan sehingga Presiden (eksekutif) memiliki ruang cukup (flexibility) untuk membuat hukum maupun untuk mengambil tindakan konkrit dalam mengatasi krisis. Tetapi di saat bersamaan penggunaan kekuasaan yang dilonggarkan pembatasannya oleh hukum tersebut haruslah dipertanggungjawabkan secara hukum dan moral (itikad baik).

Dalam the economic crisis rule approach di satu sisi, ruang intervensi dan diskresi dibuka dan para Presiden dan pejabat negara lainnya diberi kewenangan untuk merumuskan hukum, memutus hukum (keputusan) dan melaksanakan hukum (keputusan) tersebut. Tetapi di sisi lainya, aspek-aspek substansi hukum dan prosedur hukum terkait pertanggungjawaban penggunaan kekuasaan extra-ordinary yang bersifat diskresioner perlu dirumuskan secara jelas, tidak multitafsir tapi juga harus flexible untuk menyesuaikan dengan tantangan dalam situasi krisis. Dalam the economic crisis rule of law approach, hukum darurat dalam krisis ekonomi itu sekalipun dimungkinkan pemberlakuannya yang bersifat secara seketika sejak dideklarasikan, tetapi juga tetap tunduk pada pembatasan hukum, paham konstitusi dan judicial review.

Patut juga kiranya diingat bahwa ber-negara hukum dalam darurat ekonomi tidak lalu menjustifikasi perumusan hukum dan tindakan diskresi yang tidak rasional. Hukum yang dibentuk dan dilaksanakan dan diskresi yang ditempuh dalam darurat ekonomi sekalipun, sebagaimana diingatkan oleh Weber tetap harus rasional sehingga mendorong kemajuan sosial dan ekonomi (Trubek, 1972).

Ber-negara hukum dalam darurat ekonomi tidak lalu juga menjustifikasi perumusan hukum dan tindakan diskresi yang tidak efisien, tidak rasional, memakai sumber daya secara semberono dan menghilangkan kesempatan untuk menciptakan keadilan ekonomi dan keadilan hukum. 
Dalam konteks analisis ekonomi terhadap hukum (economic analysis of the law) sebagaimana ditawarkan Coase dan Becker, hukum dalam darurat ekonomi sekalipun idealnya juga merupakan hukum yang menciptakan efisiensi, rasional dan bersifat prospektif (Cooter, 2000). Karakter hukum seperti di atas penting mengingat dalam upaya untuk mengatasi krisis ekonomi tidak jarang negara juga menghabiskan sumber daya ekonomi dan hukum yang besar. Dalam konteks the economic crisis rule of law model, pengorbanan ini perlu dibarengi dengan hadirnya keadilan ekonomi dan kemakmuran bagi negara dan rakyatnya.

Ber-hukum dalam darurat ekonomi juga penting, sebgaimana ditegaskan Profesor Sywicki untuk memastikan adanya kepastian hukum (legal certainty) dan prediktabilitas (predictability). Dalam situasi krisis, seringkali koordinasi dihancurkan oleh mendadaknya ukuran ekonomi dan intervensi pemerintah yang arbiter padahal stabilitas dapat diraih jika terdapat rejim hukum yang stabil. Pendekatan kepatuhan terhadap hukum merupakan satu-satunya cara untuk meningkatkan kepercayaan para investor dan memulihkan keadaan ekonomi yang terpuruk (Zywicki, 2012).

Hukum darurat dalam keadaan krisis ekonomi, demikian lanjut Profesor Sywicki, harus pula mampu mencegah perilaku rent-seeking eksekutif (termasuk affiliasi ekonomi dan politiknya, ditambahkan Penulis). Dalam amatannya terhadap banyak kasus talangan keuangan (financial bailouts) terutama saat krisis keuangan di Amerika akibat bangkrutnya Lehman Brothers di tahun 2008, terjadi moral hazard yang menyumbang bagi ketidakpastian (uncertainty) dan menguntungkan kelompok kepentingan tertentu seperti insitusi keuangan dan politisi. Celakanya semua keuntungan ini dibayar dengan menggunakan pajak rakyat (Zywicki, 2012).

Situasi moral hazard di Amerika di atas juga terjadi di Indonesia ketika terjadi skandal bantuan likuiditas Bank Indonesia (BLBI) tahun 1999. Saat itu terjadi upaya penyehatan perbankan di Indonesia oleh Badan Penyehatan Perbankan Nasional (BPPN) ketika terjadi krisis keuangan. BLBI yang diberikan kepada ke 48 bank yang direkapitalisasi saat itu menggunakan uang negara yang berasal dari pajak dalam jumlah fantastis yakni Rp. 144,5 triliun. Sementara aset yang dijaminkan bank-bank penerima BLBI hanya mencapai Rp. 12.3 triliun (Tumenggung, 2019). Skandal BLBI merupakan tragedi terburuk dan perampokan uang rakyat sistematis yang dibungkus kebijakan arbiter dan dikresioner yang semberono oleh Bank Indonesia yang berakibat pada ketidakkepastian hukum hingga saat ini.

Penting untuk dicatat bahwa, dalam kasus krisis ekonomi dan keuangan yang terjadi di Amerika dan di Indonesia di atas, krisis ekonomi tersebut terjadi dalam sebuah negara berdaulat yang secara politik dan hukum. Artinya, dalam kasus di atas Indonesia dan Amerika, yang secara independen membuat atau mendeklarasikan hukum darurat ekonomi yang tepat dalam mengatasi krisis ekonomi tersebut. Namun, pendekatan model negara hukum di negara 'union' seperti Uni Eropa (European Union) dalam menghadapi krisis ekonomi tidak bisa disamakan dengan negara bukan 'union'. Dalam kasus krisis ekonomi (baca hutang) di Yunani, Irlandia Utara dan Portugis, ketiga negara ini tidak independen membuat hukum darurat ekonominya sendiri dalam merespons krisis yang terjadi (Gibbs, 2016) melainkan dideterminasi oleh apa yang disebut oleh Jurgen Habermas sebagai sebagai 'executive federalism' suatu keadaan dimana ekonomi dan politik terintegrasi sedemikian dalamnya sehinggga hukum dalam darurat ekonomi bukan ditentukan oleh mekanisme keterlibatan politik yang demokratis di masing-masing negara tetapi ditentukan oleh institusi Uni Eropa (Habermas, 2015).

Dengan demikian sekalipun dalam the economic crisis rule of law approach dimungkinkan fleksibilitas yang cukup dalam penggunaan diskresi dan pembentukan Perppu/UU dalam darurat ekonomi, pada saat yang sama kepatuhan atas prinsip negara hukum juga diindahkan. Hukum darurat dalam krisis ekonomi harus memiliki karakter efisien, rasional, pasti dan dapat diprediksi, dan bertujuan untuk mendatangkan kemakmuran bagi rakyat. Dan, perlu digarisbawahi hukum darurat dalam krisis eknomi juga harus mampu mencegah petualang oportunis politik dan ekonomi memanfaatkan krisis untuk mencapai keuntungan pribadi dan 
kelompoknya. Jika ini skenarionnya, maka keduanya, baik tujuan negara hukum dan tujuan mengatasi krisis ekonomi yakni keadilan hukum dan ekonomi, dan kemakmuran dapat berjalan bersamaan (coexist). Titik temu ini sesungguhnya mencerminkan tujuan tertinggi negara hukum substantif itu sendiri yakni perlindungan terhadap harkat dan martabat manusia dan pencapaian keadilan hukum substantif, keadilan ekonomi, kesejahteraan sosial serta kemakmuran.

\section{Simpulan}

Negara hukum dan darurat ekonomi menghadirkan dua kutub pendekatan yang saling bertentangan. Di satu kutub, terdapat pandangan bahwa dalam darurat ekonomi, kepatuhan atas prinsip negara hukum tidak diperlukan. Kelonggaran atas kewenangan Presiden (eksekutif) perlu dijamin sehingga Presiden (eksekutif) memiliki kemampuan cepat untuk mengatsi krisis ekonomi. Legal and constitutional constraints tidak berlaku bagi Presiden (eksekutif). Sementara itu, di kutub lainnya, terdapat perspektif bahwa justeru dalam keadaan darurat ekonomi, kepatuhan atas negara hukum dan prinsipnya perlu semakin diperketat. Legal and constitutional constraints berlaku bagi Presiden (eksekutif).

Pertentangan di atas, oleh Penulis didamaikan dengan menghadirkan pendekatan negara hukum krisis ekonomi (the economic crisis rule of law) dimana keduanya, prinsip dan tujuan negara hukum dipatuhi tetapi pada saat bersamaan dalam upaya untuk mengatasi krisis ekonomi, Presiden (eksekutif) diberikan kewenangan dan diskresi yang cukup memadai tetapi penggunaan kewenangan dan diskresi dalam krisis ekonomi perlu dipertanggungjawabkan secara hukum dan moral (itikad baik) dan penggunaan diskresi harus pula menciptakan kepastian hukum dan prediktabilitas. Inilah hakikat negara hukum dalam darurat ekonomi atau the economic crisis rule of law approach.

Dalam the economic crisis rule of law approach dimungkinkan adanya dua pendekatan yang yang berdampingan (coexist) yakni mentaati prinsip negara hukum sekaligus memberi peluang fleksibel bagi upaya memitigasi krisis ekonomi. Untuk itu, hukum dalam darurat ekonomi idealnya tetap rasional dan efisien, serta bersifat prospektif sehingga mendorong penciptaan keadilan hukum dan ekonomi. Pada saat bersamaan, skenario ini menolong pencapaian tujuan utama negara hukum substantif yakni perlindungan harkat dan martabat manusia, keadilan, kemakmuran dan kesejahteraan sosial.

\section{DAFTAR PUSTAKA}

Altman, A. (2001). Arguing About Law. Wadsworth Publishing.

Asshiddiqie, J. (2010). Hukum Tata Negara Darurat. Rajawali Press.

Barnett, E. R. (1998). The structure of liberty: justice and the Rule of law. Oxford University Press.

Brudner, A. (1995). The unity of the common law: studies in Hegelian jurisprudence. University of California Press.

Cooter, R. and T. U. (2000). Law and Economics. Addison Wesley Longman Inc.

Farber, D. (2020). Presidential Power in a Pandemic. Legal-Planet.Org. https://legalplanet.org/2020/03/18/presidential-power-in-a-pandemic/

Forst, R. (1994). Contexts of Justice Political Philosophy beyond Liberalism and Communitarianism. California University Press.

Gibbs, A. (2016). The Economic Crisis and the Rule of Law in Europe: A Hidden Face for the Rule of Law? Hague Journal on the Rule of Law, 8(2), 323-336. 
Habermas, J. (2015). The Lure of Technocracy. Polity Press.

Joachim, F. C. (1957). Constitutional Reason of State: The Survival of the Constitutional Order. Brown University Press.

Kilpatrick, C. (2015). On the Rule of Law and Economic Emergency: The Degradation of Basic Legal Values in Europe's Bailouts. Oxford Journal of Legal Studies, 32(2), 325-353.

Kramer, M. H. (2007). Objectivity and the Rule of Law. Cambridge University Press.

Licht, A. ; C. G. and S. H. S. (2007). Culture rules: The foundations of the rule of law and other norms of governance. Economics, 35(4), 659-688.

Putusan MK Nomor 138/PUU-VII/2009, (2009). https://mkri.id/public/content/persidangan/putusan/putusan_sidang_Perkara Nomor 138PUU-VII-2009.pdf

Maxeiner, J. (2007). Legal Certainty and Legal Methods: A European Alternative to American Legal Indeterminacy? Tulane Journal of International \& Comparative Law, 15(2), 541-607.

Meyler, B. (2007). Economic Emergency and the Rule of Law. DePaul Law Review, 56(2), 539568.

O’Donnell, G. (2004). The Quality of Democracy: Why the Rule of Law Matters. Journal of Democracy, 15(4), 32-46.

Posner, E. A. and A. V. (2010). Executive Unbound: After the Madisonian Republic. Oxford University Press.

Rissy, Y. Y. W. (2020). The covid19nomic crisis rule of law approach: Identifikasi dan pencegahan skandal keuangan dan likuiditas dalam pemulihan ekonomi akibat pandemic covid19. Makalah disampaikan dalam Webinar Diskursus Hukum Terkait Pandemi Covid19 dan Penanganan Hukumnya.

Scaliat, A. (1989). The Rule of Law as a Law of Rules. The University of Chicago Law Review, 56(4), 1175-1188.

Sellers, M. and T. T. (2010). The rule of law in comparative perspective, Springer. Springer.

Supiot, A. (2010). A legal perspective on the economic crisis of 2008. International Labour Review, 149(2), 151-162.

Tamanaha, B. Z. (1994). On the Rule of Law History, Politics, Theory. Cambridge University Press.

Trubek, D. M. (1972). Toward a Social Theory of Law: An Essay on the Study of Law and Development. The Yale Law Journal, 82(1), 1-50.

Tumenggung, S. A. (2019). Bencana BLBI dan Krisis Ekonomi Indonesia. Rajawali Press.

Zywicki, T. (2012). Economic uncertainty, the courts and the Rule of law. Harvard Journal of Law and Public Policy, 35(1), 195-212.

Zywicki, T. (2015). The Rule of Law During Times of Economic Crisis. http://dx.doi.org/10.2139/ssrn.2651893 